\title{
Recent Advances in Optimization of Smart Structures and Actuators
}

\author{
MARY I. FRECKER* \\ The Pennsylvania State University, 326 Leonhard Building, \\ University Park, PA 16802, USA
}

\begin{abstract}
Much of the recent and past work in the area of smart materials and structures has focused on analysis of actuators and actively controlled systems. Although many sophisticated analysis models have been developed, they are often coupled with ad hoc design methods or informal optimization procedures. A subset of the work done by the smart structures community has focused on development of formal design methodologies and optimization methods specifically for smart actuators and structures. The objective of this paper is to review the current work in development of design methodologies and application of formal optimization methods to the design of smart structures and actuators. In a related paper, optimization strategies for sensor and actuator placement were reviewed by a researcher at NASA Langley in 1999. The current paper reviews the recent work done in this area since 1999, in addition to optimization strategies for topology design of actuators, actively controlled structures, and drive electronics design. The main focus is on piezoelectric ceramic actuators, but relevant work in shape memory alloys and magnetostrictive actuation are included as well. Future directions for research in optimization are also recommended.
\end{abstract}

Key Words: actuator optimization, smart structures optimization

\section{INTRODUCTION}

M $\mathrm{UCH}$ of the recent and past work in the area of smart materials and structures has focused on analysis of structures equipped with actuators and sensors and their associated control systems. Much of this work has been targeted at vibration control applications. Although many sophisticated analysis models, both analytical and numerical, have been developed, they are often coupled with ad hoc design methods or informal optimization procedures. A subset of the work done by the smart structures community has focused on development of formal design methodologies and optimization methods specifically for smart actuators and structures. The objective of this paper is to review the current work in development of design methodologies and application of formal optimization methods to the design of smart structures and actuators.

A large number of papers dealing with the topics of optimization and actuators were found in the literature. In an effort to narrow the scope of the current review article, several restrictions were applied and are summarized here. The work reviewed here includes only those papers dealing with smart actuators, such as piezoelectric ceramics or shape memory alloys, and not

*E-mail: mxf36@psu.edu those concerned with generic or conventional actuators. (Two papers dealing with generic actuators have been included in the review because they directly address optimization of smart structures.) Papers dealing solely with control systems have not been included. Further, only those papers describing the development and/or use of formal optimization techniques are included. Informal optimization consisting of parameter variation studies using analysis models are not considered. In addition, the review presented here has been restricted to include only journal articles published in the past three years. A review of optimization strategies for sensor and actuator placement was conducted in 1999 by a researcher at NASA Langley (Padula and Kincaid, 1999); the current paper reviews the work in optimal actuator placement, as well as other relevant work, since then.

Optimal actuator placement is the topic of a large portion of the recent work in smart structures optimization. But there are also a number of papers describing other aspects of optimization in smart structures such as optimal design of coupled actuator-controller parameters, drive electronics, and coupling structures for single actuators. The papers reviewed here have been classified into one of five categories as listed in Table 1. Each category is described in detail in the subsequent sections. In the current review, each paper is described in 
terms of its objective function(s), design variables, constraints, solution method, actuator type, and target application.

\section{Table 1. Classification of optimization strategies for} smart structures.

\begin{tabular}{lc}
\hline Actuator Placement & $\begin{array}{c}\text { Location of actuators on } \\
\text { predetermined structures } \\
\text { Actuator Placement-Controller location and controller } \\
\text { parameters on predetermined } \\
\text { Electronics }\end{array}$ \\
$\begin{array}{c}\text { structures } \\
\text { Drive electronics parameters } \\
\text { for a particular actuator } \\
\text { Coupling structure for a } \\
\text { particular actuator }\end{array}$ \\
Actuator-Structure & Coupling structure and actuator \\
\hline
\end{tabular}

\section{ACTUATOR PLACEMENT}

The largest body of work related to optimization of smart structures can be categorized as optimal actuator placement, where the optimal locations of actuators are found for predetermined structures. The size of actuators may be optimized as well in actuator placement problems, but the passive structure is assumed to be of predetermined geometry and material. Almost all of this work is focused on optimal placement of piezoelectric actuator patches on simple structures such as on beams or plates. The papers dealing with optimal actuator placement are summarized in Table 2.

In the papers addressing beam problems, it is usually assumed that symmetric pairs of actuator patches are perfectly bonded to the top and bottom surfaces of the beam, and the actuator pairs are to be optimally placed along the length of a beam. In Suleman and Goncalves

Table 2. Actuator placement optimization summary.

\begin{tabular}{|c|c|c|c|c|c|c|}
\hline Source & $\begin{array}{l}\text { Objective } \\
\text { Function }\end{array}$ & $\begin{array}{l}\text { Design } \\
\text { Variables }\end{array}$ & $\begin{array}{l}\text { Constraint } \\
\text { Function(s) }\end{array}$ & $\begin{array}{l}\text { Solution } \\
\text { Method }\end{array}$ & Actuator Type & Application \\
\hline $\begin{array}{l}\text { Suleman and } \\
\text { Goncalves (1999) }\end{array}$ & $\begin{array}{l}\text { Max(displacement) } \\
\text { and min(mass of } \\
\text { actuators) and } \\
\text { min(vottage) }\end{array}$ & $\begin{array}{l}\text { Actuator size, } \\
\text { thickness, } \\
\text { and locations }\end{array}$ & $\begin{array}{l}\text { Actuator } \\
\text { geometry; } \\
\text { upper and } \\
\text { lower limits } \\
\text { on design } \\
\text { variables }\end{array}$ & $\begin{array}{l}\text { Physical } \\
\text { Programming }\end{array}$ & $\begin{array}{l}4 \text { pairs of } \\
\text { piezoelectric } \\
\text { actuator } \\
\text { patches }\end{array}$ & $\begin{array}{l}\text { Cantilever } \\
\text { rectangular } \\
\text { laminated } \\
\text { composite } \\
\text { beam }\end{array}$ \\
\hline $\begin{array}{l}\text { Adali } \\
\text { et al. (2000) }\end{array}$ & $\begin{array}{l}\text { Min(max } \\
\text { deflection) }\end{array}$ & $\begin{array}{l}\text { Actuator } \\
\text { location }\end{array}$ & Not specified & $\begin{array}{l}\text { One-dimensional } \\
\text { optimization } \\
\text { algorithm }\end{array}$ & $\begin{array}{l}1 \text { pair of } \\
\text { piezoelectric } \\
\text { actuator } \\
\text { patches }\end{array}$ & $\begin{array}{l}\text { Laminated } \\
\text { beam }\end{array}$ \\
\hline $\begin{array}{l}\text { Aldraihem } \\
\text { et al. (2000) }\end{array}$ & $\begin{array}{l}\text { Max (weighted } \\
\text { controllability) }\end{array}$ & $\begin{array}{l}\text { Actuator } \\
\text { length and } \\
\text { locations }\end{array}$ & $\begin{array}{l}\text { Distance to } \\
\text { the end of } \\
\text { the next patch }\end{array}$ & $\begin{array}{l}\text { Unspecified } \\
\text { iterative }\end{array}$ & $\begin{array}{l}\text { Pairs of } \\
\text { piezoelectric } \\
\text { actuator } \\
\text { patches }\end{array}$ & $\begin{array}{l}\text { Simply } \\
\text { supported } \\
\text { or cantilever } \\
\text { beam }\end{array}$ \\
\hline $\begin{array}{l}\text { Barboni } \\
\text { et al. (2000) }\end{array}$ & $\begin{array}{l}\text { Max (displacement } \\
\text { generated by } \\
\text { actuator) }\end{array}$ & $\begin{array}{l}\text { Actuator } \\
\text { length and } \\
\text { location }\end{array}$ & Unconstrained & $\begin{array}{l}\text { Analytical } \\
\text { solution of } \\
\text { optimality } \\
\text { conditions }\end{array}$ & $\begin{array}{l}1 \text { pair of } \\
\text { piezoelectric } \\
\text { actuator } \\
\text { patches }\end{array}$ & $\begin{array}{l}\text { Simply } \\
\text { supported } \\
\text { beam }\end{array}$ \\
\hline $\begin{array}{l}\text { Bruant } \\
\text { et al. (2001) }\end{array}$ & $\begin{array}{l}\text { Min(mechanical } \\
\text { energy integral); } \\
\text { max(measure } \\
\text { of observability } \\
\text { grammian) }\end{array}$ & $\begin{array}{l}\text { Actuator } \\
\text { length and } \\
\text { location; } \\
\text { sensor } \\
\text { location }\end{array}$ & Unconstrained & $\begin{array}{l}\text { Gradient } \\
\text { algorithm }\end{array}$ & $\begin{array}{l}1 \text { pair of } \\
\text { piezoelectric } \\
\text { actuator } \\
\text { patches and } \\
1 \text { pair of } \\
\text { sensor } \\
\text { patches }\end{array}$ & $\begin{array}{l}\text { Cantilever } \\
\text { beam, 3-beam } \\
\text { structure }\end{array}$ \\
\hline $\begin{array}{l}\text { Han and } \\
\text { Lee (1999) }\end{array}$ & $\begin{array}{l}\text { Max(steady } \\
\text { state contollability } \\
\text { Grammian) }\end{array}$ & $\begin{array}{l}\text { Actuator } \\
\text { locations, } \\
\text { sensor } \\
\text { locations }\end{array}$ & Not specified & GA & $\begin{array}{l}2 \text { piezoelectric } \\
\text { actuator } \\
\text { patches } \\
\text { and } 2 \\
\text { piezofilm } \\
\text { sensors }\end{array}$ & $\begin{array}{l}\text { Cantilever } \\
\text { composite } \\
\text { plate }\end{array}$ \\
\hline $\begin{array}{l}\text { Sadri } \\
\text { et al. (1999) }\end{array}$ & $\begin{array}{l}\text { Max (modal } \\
\text { controllability) } \\
\text { or max } \\
\text { (controllability } \\
\text { Grammian) }\end{array}$ & $\begin{array}{l}\text { Coordinates } \\
\text { of center } \\
\text { of actuators, } \\
\text { or size of } \\
\text { actuators }\end{array}$ & Unconstrained & GA & $\begin{array}{l}2 \text { rectangular } \\
\text { piezoelectric } \\
\text { actuator } \\
\text { patches }\end{array}$ & $\begin{array}{l}\text { Simply } \\
\text { supported } \\
\text { isotropic } \\
\text { plate }\end{array}$ \\
\hline $\begin{array}{l}\text { Sheng and } \\
\text { Kapania (2001) }\end{array}$ & $\begin{array}{l}\text { Min(thermal } \\
\text { distortions) }\end{array}$ & Actuator locations & & GA & $\begin{array}{l}\text { Piezoelectric } \\
\text { strips }\end{array}$ & $\begin{array}{l}\text { Primary } \\
\text { surface } \\
\text { mirror }\end{array}$ \\
\hline
\end{tabular}


(1999), several objective functions are considered simultaneously such as maximizing the average static vertical displacement of the beam and minimizing the mass of the actuators and minimizing the actuation voltage. The design variables are the coordinates of actuator pairs, the size of rectangular actuator patches, and the thickness of actuator patches. Geometric constraints are imposed to prevent superposition of actuators and the actuators being placed out of order. Upper and lower limits are also placed on the design variables. The multiple objectives are handled using the physical programming approach (Messac, 1996). In physical programming the designer specifies hard constraints and soft constraints as highly desirable to highly undesirable, thus eliminating the need for weighting factors in multiobjective optimization.

Adali et al. (2000) consider a beam problem where the maximum vertical deflection of a laminated beam is to be minimized using one pair of actuators. The distance of the actuator pair from the support is taken as the design variable. In their robust design approach external loads are not known a priori, but belong to specified uncertainty domain. The solution method is described only as a one-dimensional optimization algorithm. In Aldraihem et al. (2000) the objective is to maximize the weighted controllability of a simply supported or cantilever beam. Pairs of piezoelectric actuator patches are placed such that they provide maximum controllability for weighted modes, where the weights on modes are determined by ranking their contribution to overall system response. As a way to constrain the length of the actuator, a penalty function is included in the objective function. The pairs of piezoelectric patches are assumed to have equal thickness and width, and to be self-sensing. The mass and stiffness of the actuators are included in dynamic model but the bonding layers are neglected. The solution method is described only as an iterative procedure. Barboni et al. (2000) consider a beam vibration problem where the objective is to maximize the displacement generated by a pair of actuators. The position of the actuator along the beam and the actuator length are taken as the design variables. The optimization problem is solved analytically using a closed form solution of the optimality conditions. Bruant et al. (2001) optimize both sensor and actuator locations, but consider them separately. The actuator length and location are found first by minimizing the mechanical energy integral, then the sensor location is found by maximizing a measure of the observability Grammian. Examples of a cantilever beam and a threebeam structure are presented.

A plate problem is considered by Han and Lee (1999), where the steady state controllability Grammian is used as a way to maximize the eigenvalues. A genetic algorithm (GA) is used to find the optimal locations of two actuators from a set of 99 possible rectangular areas on the plate. The optimal locations of two sensors are then found in a second stage. A similar approach is taken by Sadri et al. (1999) where measures of controllability, modal controllability or controllability Grammian, are maximized. A genetic algorithm is used to place two piezoelectric actuators on a simply supported isotropic plate. The optimal sizing of the actuators is considered separately.

Other applications for optimal actuator placement have been considered such as a thin hexagonal spherical primary surface mirror (Sheng and Kapania, 2001). In this paper the authors seek to minimize the thermal distortions of the mirror. Four thermal distortions are considered, and solutions are found for each load applied individually, then all four loads simultaneously. A genetic algorithm is used to find 30 optimal actuator locations from a set of 93 possible locations. Optimal voltages are also mentioned, but are not found in the accompanying examples.

\section{ACTUATOR PLACEMENT-CONTROLLER}

In this section, papers are discussed which deal with combined optimization of actuator locations and controller parameters. Many of these papers assume that sensors are collocated with actuators. Controller parameters such as feedback gain or actuation voltages are optimized either simultaneously or in sequence with actuator locations. The actuator placement-controller papers are summarized in Table 3.

Beam problems are considered by both Hiramoto et al. (2000) and Zhang et al. (2000). Zhang et al. (2000) consider the problem of maximizing the energy dissipated by the active controller by optimizing the actuator and sensor locations and the value of the feedback gain. A float-encoded genetic algorithm is used to solve the optimization problem. Results from a simulation of a cantilever beam with collocated sensors and actuators are shown to be comparable to a previously published result, with significantly less computation time than the quasi-Newton method. Hiramoto et al. (2000) propose an iterative method to design both the location of collocated sensors and actuators and the controller. The objective is to minimize the closed loop transfer function with weighted frequencies. The solution procedure begins with a candidate set of actuator-sensor placements, then calculates an optimal controller and iterates until the optimal placement is found. An explicit solution of the Ricatti equations is used to show that an Hinf controller is obtained, but the controller is not simultaneously optimized. The quasi-Newton method, a gradient-based method, is used to solve using several random starting points. 
Table 3. Actuator placement-controller optimization summary.

\begin{tabular}{|c|c|c|c|c|c|c|}
\hline Source & $\begin{array}{l}\text { Objective } \\
\text { Function }\end{array}$ & $\begin{array}{l}\text { Design } \\
\text { Variables }\end{array}$ & $\begin{array}{l}\text { Constraint } \\
\text { Function(s) }\end{array}$ & $\begin{array}{l}\text { Solution } \\
\text { Method }\end{array}$ & $\begin{array}{l}\text { Actuator } \\
\text { Type }\end{array}$ & Application \\
\hline $\begin{array}{l}\text { Zhang } \\
\text { et al. (2000) }\end{array}$ & $\begin{array}{l}\text { Max(energy } \\
\text { dissipated } \\
\text { by active } \\
\text { controller) }\end{array}$ & $\begin{array}{l}\text { Actuator } \\
\text { and sensor } \\
\text { locations, } \\
\text { value of } \\
\text { feedback } \\
\text { gain }\end{array}$ & $\begin{array}{l}\text { Upper and } \\
\text { lower limits } \\
\text { on design } \\
\text { variables }\end{array}$ & $\begin{array}{l}\text { Float- } \\
\text { encoded } \\
\text { GA }\end{array}$ & $\begin{array}{l}\text { Piezoelectric } \\
\text { actuator } \\
\text { patches }\end{array}$ & $\begin{array}{l}\text { Cantilever beam } \\
\text { w/ collocated } \\
\text { sensors and } \\
\text { actuators }\end{array}$ \\
\hline $\begin{array}{l}\text { Hiramoto } \\
\text { et al. (2000) }\end{array}$ & $\begin{array}{l}\text { Min(closed } \\
\text { loop transfer } \\
\text { function) }\end{array}$ & $\begin{array}{l}\text { Sensor/actuator } \\
\text { location } \\
\text { using Hinf } \\
\text { (optimal) } \\
\text { controller }\end{array}$ & Unconstrained & $\begin{array}{l}\text { Quasi- } \\
\text { Newton } \\
\text { method }\end{array}$ & $\begin{array}{l}2 \text { piezoelectric } \\
\text { actuator/sensor } \\
\text { patches }\end{array}$ & $\begin{array}{l}\text { Simply supported } \\
\text { beam }\end{array}$ \\
\hline Gao et al. (2000) & $\begin{array}{l}\text { Min(total } \\
\text { radiated } \\
\text { acoustic } \\
\text { power), or } \\
\text { min(acoustic } \\
\text { potential } \\
\text { energy) }\end{array}$ & $\begin{array}{l}\text { Location of } \\
\text { actuators } \\
\text { and voltages }\end{array}$ & Unconstrained & $\begin{array}{l}\text { GA with } \\
\text { immune } \\
\text { diversity }\end{array}$ & $\begin{array}{l}\text { Piezoelectric } \\
\text { actuator } \\
\text { patches }\end{array}$ & $\begin{array}{l}\text { Simply supported } \\
\text { thin plate }\end{array}$ \\
\hline $\begin{array}{l}\text { Li et al. } \\
(2001)\end{array}$ & $\begin{array}{l}\text { Min(radiated } \\
\text { acoustic } \\
\text { power) }\end{array}$ & $\begin{array}{l}\text { Applied } \\
\text { voltages; } \\
\text { location, } \\
\text { size, and } \\
\text { number of } \\
\text { actuators } \\
\text { (indirectly) }\end{array}$ & $\begin{array}{l}\text { Limit on } \\
\text { amplitude } \\
\text { of control } \\
\text { voltage }\end{array}$ & QP & $\begin{array}{l}\text { Piezoelectric } \\
\text { patches }\end{array}$ & $\begin{array}{l}\text { Simply supported } \\
\text { rectangular plate }\end{array}$ \\
\hline $\begin{array}{l}\text { Heverly II } \\
\text { et al. (2001) }\end{array}$ & $\begin{array}{l}\text { Min(vibration } \\
\text { and control } \\
\text { effort); } \\
\text { min(sum of } \\
\text { objectives } \\
\text { at different } \\
\text { loading } \\
\text { conditions) }\end{array}$ & $\begin{array}{l}\text { Actuator } \\
\text { locations, } \\
\text { control gains }\end{array}$ & $\begin{array}{l}\text { Upper } \\
\text { limit on } \\
\text { vibration } \\
\text { at nontarget } \\
\text { nodes, upper } \\
\text { limit on } \\
\text { control force }\end{array}$ & $\begin{array}{l}\text { SA with } \\
\text { optimal } \\
\text { control }\end{array}$ & $\begin{array}{l}\text { FAU or } \\
\text { MAU }\end{array}$ & Helicopter airframe \\
\hline
\end{tabular}

Plate problems are also considered by a few authors. Gao et al. (2000) consider a vibration suppression problem where the objective is to minimize the total radiated acoustic power or the acoustic potential energy. They use the location of piezoelectric patches and the actuation voltages as design variables. The optimal control parameters (voltages) are found using a conventional minimization for quadratic function, and the actuator locations are found using a genetic algorithm with immune diversity. The GA with immune diversity is shown to produce better solutions than a simple genetic algorithm. Li et al. (2001) address a similar problem in the design for acoustic control of a simply supported rectangular plate. A finite element mesh of actuator patches on the top and bottom surfaces of the plate is used. The voltage to each actuator element is optimized using a conventional minimization procedure for quadratic function, presumably a quadratic programming method (QP). The actuators are placed indirectly, i.e., if the voltage is too large or too small the patch is deleted.The optimized plate is shown to have reduced acoustic power at a number of modes.
Helicopter airframe-based vibration control is the focus of Heverly et al.'s paper (2001), where an optimal control law is coupled with actuator placement. The objective function is a weighted sum of vibration and control effort with a penalty function on vibration at nontarget locations or nodes. The penalty function is active only when constraints on nontarget nodes are violated. Different loading conditions at the tail and at the hub and tail are also considered by combining the objective functions for each loading condition. The integer values of actuator locations and the control gains of each actuation unit are the design variables. The type of actuation unit, force or moment actuation units (FAU or MAU), are determined based on the actuator locations. An upper limit on the vibration response at nodes not targeted for vibration reduction is imposed, as well as an upper limit on the control force. A simulated annealing (SA) algorithm coupled with optimal control is used to solve the optimization problem. Each time the set of actuator locations is updated by the SA, the corresponding active control gains are updated. This approach is shown to be effective in significantly 
reducing vibration and control effort for the helicopter airframe problem.

\section{ELECTRONICS}

Although the optimization of actuator and controller parameters has received much of the attention of smart structures researchers, much less attention has been paid to the optimal design of the drive electronics system. Chandrasekaran et al. (2000) have developed a method to optimally design a current-controlled switching power amplifier to drive a piezoelectric actuator. An analytical model of a piezoelectric ceramic material is developed that includes the anhysteretic nonlinearity between electric field and polarization. The material model is coupled with a model of a given circuit topology in the switching amplifier. The objective is to minimize the weight of the entire electrical amplifier, which is assumed to be comprised primarily of the inductor. The inductor is assumed to be a typical EE core and its weight is taken to be the sum of the weight of the iron and copper used in the core and windings. The inductor geometry and other properties are used as the design variables. An upper limit is placed on the ratio of total harmonic distortion (THD) or ripple current of the actuator or the size of the inductor at a specified switching frequency. There are also physical constraints on core and winding dimensions. The modified method of feasible directions (MMF) algorithm, which is a gradient based method, is used to solve the optimization problem. The actuator type is a piezoelectric stack or $d_{33}$-type actuator. A family of optimal designs is obtained by varying the upper limit on the THD of the actuator for frequencies of 100 and $200 \mathrm{kHz}$ (Table 4).

\section{STRUCTURE}

A number of papers address the problem of designing coupling structures for piezoelectric actuators. This approach is in contrast to the actuator placement approach where actuators are sized and/or placed on predetermined structures. In structure optimization, the structure is optimally designed for one or more predetermined actuators. Most of the papers in this review are concerned with topology optimization, where the goal is to determine an optimal structural connectivity of material. Topology optimization can be thought of as defining the number, size, and location of holes in a structure. Various methods to parameterize the design domain are used in topology optimization such as prescribing a mesh of square elements or a dense network of linear elements called a ground structure. The structure optimization papers are summarized in Table 5.

The ground structure approach has been employed by Frecker and Canfield (2000) and Canfield and Frecker (2000) to design compliant mechanisms to act as stroke amplifiers for piezoelectric stack actuators. The objective functions are to maximize the geometric advantage (stroke amplification) or to maximize the mechanical efficiency. In the ground structure approach, a network of truss or frame elements is prescribed and the crosssectional areas of the elements are the design variables. The lower limit on the design variables is set at a very small number, so that the elements that reach the lower limit can be ignored and the remaining elements define the optimal topology. A total volume constraint is also imposed to limit the weight or amount of material that is used. The sequential linear programming (SLP) method, or an optimality criteria method (OC) are used to solve the optimization problems.

Kota et al. (1999) also consider the problem of designing stroke amplifying compliant mechanisms using the ground structure approach. They examine various energy-based objective functions including maximizing the mechanical efficiency. These authors have taken the topology optimization solution a step further by proposing a second-stage size and shape optimization procedure. The optimal topology is defined using the ground structure approach and SLP solution algorithm. Then the shape of the topology is refined by allowing nodes to wander and by further

Table 4. Electronics optimization summary.

\begin{tabular}{|c|c|c|c|c|c|c|}
\hline Source & $\begin{array}{l}\text { Objective } \\
\text { Function }\end{array}$ & Design Variables & $\begin{array}{l}\text { Constraint } \\
\text { Function(s) }\end{array}$ & $\begin{array}{l}\text { Solution } \\
\text { Method }\end{array}$ & $\begin{array}{l}\text { Actuator } \\
\text { Type }\end{array}$ & Application \\
\hline $\begin{array}{l}\text { Chandrasekaran } \\
\text { et al. (2000) }\end{array}$ & $\begin{array}{l}\text { Min (inductor } \\
\text { weight) }\end{array}$ & $\begin{array}{l}\text { Number of } \\
\text { turns, cross- } \\
\text { sectional area } \\
\text { of windings, } \\
\text { center leg } \\
\text { width, window } \\
\text { width, airgap length }\end{array}$ & $\begin{array}{l}\text { Upper limit } \\
\text { on THD of } \\
\text { actuator } \\
\text { current to } \\
\text { inductor size, } \\
\text { physical } \\
\text { constraints } \\
\text { on core and } \\
\text { winding } \\
\text { dimensions }\end{array}$ & MMF & $\begin{array}{l}\text { PZT } \\
\text { stack }\end{array}$ & $\begin{array}{l}\text { Design of } \\
\text { current-controlled } \\
\text { switching power } \\
\text { amplifier to drive } \\
\text { PZT actuator }\end{array}$ \\
\hline
\end{tabular}


Table 5. Structure optimization summary.

\begin{tabular}{|c|c|c|c|c|c|c|}
\hline Source & $\begin{array}{l}\text { Objective } \\
\text { Function }\end{array}$ & Design Variables & $\begin{array}{l}\text { Constraint } \\
\text { Function(s) }\end{array}$ & $\begin{array}{l}\text { Solution } \\
\text { Method }\end{array}$ & $\begin{array}{l}\text { Actuator } \\
\text { Type }\end{array}$ & Application \\
\hline $\begin{array}{l}\text { Frecker and } \\
\text { Canfield (2000) }\end{array}$ & $\begin{array}{l}\text { Max(geometric } \\
\text { advantage) }\end{array}$ & $\begin{array}{l}\text { Cross- sectional } \\
\text { area of truss } \\
\text { and frame } \\
\text { elements }\end{array}$ & $\begin{array}{l}\text { Upper limit } \\
\text { on volume, } \\
\text { upper and } \\
\text { lower limit } \\
\text { on design } \\
\text { variables }\end{array}$ & SLP & $\begin{array}{l}\text { PZT } \\
\text { stack } \\
\text { modeled } \\
\text { as a rod } \\
\text { element }\end{array}$ & $\begin{array}{l}\text { Stroke amplifying } \\
\text { compliant mechanisms } \\
\text { for stack actuators }\end{array}$ \\
\hline $\begin{array}{l}\text { Canfield and } \\
\text { Frecker (2000) }\end{array}$ & $\begin{array}{l}\text { Max(geometric } \\
\text { advantage), } \\
\text { max (mechanical } \\
\text { efficiency) }\end{array}$ & $\begin{array}{l}\text { Cross- } \\
\text { sectional area } \\
\text { of truss and } \\
\text { frame elements }\end{array}$ & $\begin{array}{l}\text { Upper limit } \\
\text { on volume, } \\
\text { upper and } \\
\text { lower limit } \\
\text { on design } \\
\text { variables }\end{array}$ & SLP or OC & $\begin{array}{l}\text { PZT stack } \\
\text { modeled } \\
\text { as a rod } \\
\text { element }\end{array}$ & $\begin{array}{l}\text { Stroke amplifying } \\
\text { compliant mechanisms } \\
\text { for stack actuators }\end{array}$ \\
\hline $\begin{array}{l}\text { Kota } \\
\text { et al. (1999) }\end{array}$ & $\begin{array}{l}\text { Max (mechanical } \\
\text { efficiency) }\end{array}$ & $\begin{array}{l}\text { Cross-sectional } \\
\text { areas of beam } \\
\text { elements }\end{array}$ & $\begin{array}{l}\text { Upper limit } \\
\text { on volume, } \\
\text { upper and } \\
\text { lower limit } \\
\text { on design } \\
\text { variables; } \\
\text { upper limit } \\
\text { on stress }\end{array}$ & SLP & $\begin{array}{l}\text { Generic } \\
\text { actuator }\end{array}$ & $\begin{array}{l}\text { MEMS actuator, } \\
\text { shape control }\end{array}$ \\
\hline $\begin{array}{l}\text { Nelli Silva } \\
\text { et al. (1999) }\end{array}$ & $\begin{array}{l}\text { Max(hydrostatic } \\
\text { coupling } \\
\text { coefficient) or } \\
\text { max(hydrostatic } \\
\text { figure of merit) } \\
\text { or max(hydrostatic } \\
\text { electromechanical } \\
\text { coupling factor); } \\
\text { Max(mean } \\
\text { transduction) and } \\
\text { min(mean } \\
\text { compliance) }\end{array}$ & Element densities & $\begin{array}{l}\text { Upper limit } \\
\text { on volume, } \\
\text { upper and } \\
\text { lower limits } \\
\text { on design } \\
\text { variables, } \\
\text { lower limit } \\
\text { on effective } \\
\text { stiffness }\end{array}$ & SLP & $\begin{array}{l}\text { Generic PZT } \\
\text { actuator } \\
\text { modeled as } \\
\text { set of square } \\
\text { PZT elements }\end{array}$ & $\begin{array}{l}\text { Microstructures for } \\
\text { hydrophone, flextensional }\end{array}$ \\
\hline $\begin{array}{l}\text { Nelli Silva } \\
\text { et al. (2000) }\end{array}$ & $\begin{array}{l}\text { Max(mean } \\
\text { transduction) } \\
\text { and min(mean } \\
\text { compliance) }\end{array}$ & Element densities & $\begin{array}{l}\text { Upper limit } \\
\text { on volume, } \\
\text { upper and } \\
\text { lower limits } \\
\text { on design } \\
\text { variables }\end{array}$ & SLP & $\begin{array}{l}\text { Generic PZT } \\
\text { actuator } \\
\text { modeled as } \\
\text { set of square } \\
\text { PZT elements }\end{array}$ & Flextensional \\
\hline $\begin{array}{l}\text { Sigmund and } \\
\text { Torquato (1999) }\end{array}$ & $\begin{array}{l}\text { Max(effective } \\
\text { hydrostatic } \\
\text { charge } \\
\text { coefficient); } \\
\text { max(electromechanical } \\
\text { coupling factor) }\end{array}$ & Element densities & $\begin{array}{l}\text { Upper limit } \\
\text { on volume, } \\
\text { upper and } \\
\text { lower limits } \\
\text { on design } \\
\text { variables }\end{array}$ & SLP & $\begin{array}{l}\text { Piezoelectric } \\
\text { rods }\end{array}$ & $\begin{array}{l}\text { Material microstructure } \\
\text { far hydrophone }\end{array}$ \\
\hline $\begin{array}{l}\text { Du } \\
\text { et al. (2000), } \\
\text { Lau } \\
\text { et al. (2000) }\end{array}$ & $\begin{array}{l}\text { Max(output stroke) } \\
\text { or max(magnification } \\
\text { factor) or } \\
\text { max(mechanical } \\
\text { efficiency) }\end{array}$ & $\begin{array}{l}\text { Thickness of } \\
\text { plane stress } \\
\text { elements }\end{array}$ & $\begin{array}{l}\text { Upper bound } \\
\text { on volume, } \\
\text { upper and } \\
\text { lower bounds } \\
\text { on element } \\
\text { thicknesses }\end{array}$ & MMA & $\begin{array}{l}\text { PZT stack } \\
\text { modeled as } \\
\text { a rod element }\end{array}$ & Dot matrix printer head \\
\hline
\end{tabular}

sizing the individual elements. Stress constraints are difficult to enforce at the topology optimization stage due to their local nature, but stress constraints have been incorporated in the shape/size optimization with obvious practical benefits. In the optimization the input force is assumed to be known and to be provided by a generic source. But examples are presented including a stroke amplifying microcompliant mechanism and a shape control compliant mechanism actuated by a SMA wire.

Nelli Silva et al. $(1999,2000)$ use the homogenization method for topology optimization of piezoelectric composite material microstructures and flextensional actuators or passive coupling structures for piezoelectric actuators. In the material microstructure problem the objective functions are maximizing the hydrostatic 
coupling coefficient, maximizing the hydrostatic figure of merit, or maximizing the hydrostatic electromechanical coupling factor. These problems are all formulated as the design of a material microstructure with prescribed piezoelectric composite properties, but the piezoelectric elements in the microstructure are predetermined and are not optimized themselves. They also propose a combination of maximizing the mean transduction and minimizing the mean compliance of passive coupling structures. A generic piezoelectric actuator is modeled as a set of square piezoelectric elements. In both types of problems the homogenization method is used to calculate effective elastic properties of the microstructure, which is parameterized as a perforated structure with rectangular holes. The size and orientation of the holes serve as the design variables, and can be thought of as the element densities. The constraints consist of an upper limit on the total volume of material and bounds on the design variables. A penalty function for intermediate elements and a limit on the effective stiffness are also included. The SLP method is used to solve the optimization problems.

Sigmund and Torquato (1999) employ a very similar approach in designing piezoelectric composite material microstructures. In their approach, a composite material consisting of a soft polymer material with piezoelectric rods through the thickness is assumed. The topology optimization method is used to design the material microstructure of the polymer matrix in the composite material. The topology of the piezoelectric rods remains fixed, but their volume fraction is varied in the optimization. The objective functions are maximizing the effective hydrostatic charge coefficient, or maximizing the square of the electromechanical coupling factor. The simple isotropic material with penalization (SIMP) approach is used to parameterize the design domain, where the element densities are the design variables and a penalization is included to avoid elements with intermediate densities. The homogenization method is used to calculate the effective material properties. A total volume constraint and upper and lower bounds on design variables are imposed. Additional constraints can be imposed on the elastic coefficients to enforce isotropy or orthotropy of the resulting material microstructure. The SLP method is used to solve the optimization problem. Three dimensional material microstructures are presented as examples.

Du et al. (2000) and Lau et al. (2000) have considered optimizing a coupling structure including dynamic analysis. A piezoelectric stack actuator is modeled as a single rod element. The objective functions include the maximization of the output stroke of the structure, maximization of the magnification factor, or maximization of mechanical efficiency. The variable element density approach is used, where the design domain for the structure is parameterized into square elements, and the thicknesses of each element are used as the design variables. The lower limit is set to a small value near zero so that the elements that reach the lower limit can be considered as void and the remaining elements define the optimal topology. The method of moving asymptotes (MMA) is used to solve the optimization problem and the method is applied to a dot matrix printer head example.

\section{STRUCTURE-ACTUATOR}

A more general approach to optimally designing smart structures is to simultaneously optimize both the actuator and surrounding structure. Full topology optimization has not yet been accomplished for this problem, but several papers exist for structures of fixed topologies such as beams or plates. The structureactuator papers are summarized in Table 6 .

Gehring et al. (2000) have developed an analytical model to optimize micro-sized bimorph actuators made of piezoelectric and magnetostrictive materials. They solve the problems of maximizing the free deflection, maximizing the blocked force, or maximizing the actual force at the tip. The design variables are the ratio of the thicknesses or the ratio of the Young's moduli of the active and passive materials, or the length. The optimization is done directly through an analytical solution of the optimality conditions.

Lu et al. (2001) have developed an analytical model to optimize a SMA plate actuator equipped with passive corrugated core. The goal is to minimize the weight by designing the plate thickness, core member thickness, total length, and total height. Detailed analytical models are derived for yielding, cracking, and buckling of the SMA plate, and for the actuator deflection. Constraints include a lower limit on deflection, upper limit on power consumption, upper limit on face stress, upper limit on core member stress, buckling constraints of face and core, and lower limit on fundamental frequency. A combination of graphical and sequential quadratic programming (SQP) methods are used to solve the optimization problem.

Begg and Liu (2000) combine simulated annealing and SLP/SQP methods to optimally design an active truss. The objective functions of minimizing the quadratic index, which is related to vibration, or maximizing robustness, or maximizing controllability are considered. The design variables are the cross-sectional areas of the truss elements and the actuator locations. A shape function parameter is also designed for a 25 bar truss example. The continuous problem of designing the truss member sizes is handled by SLP or SQP methods, and the discrete problem of locating actuators is handled by a SA algorithm. The two solution methods are used either in sequence or in a combined hybrid approach. 
Table 6. Structure-Actuator optimization summary.

\begin{tabular}{|c|c|c|c|c|c|c|}
\hline Source & $\begin{array}{l}\text { Objective } \\
\text { Function }\end{array}$ & $\begin{array}{l}\text { Design } \\
\text { Variables }\end{array}$ & $\begin{array}{l}\text { Constraint } \\
\text { Function(s) }\end{array}$ & $\begin{array}{l}\text { Solution } \\
\text { Method }\end{array}$ & $\begin{array}{l}\text { Actuator } \\
\text { Type }\end{array}$ & Application \\
\hline $\begin{array}{l}\text { Gehring } \\
\text { et al. (2000) }\end{array}$ & $\begin{array}{l}\text { Max(free tip } \\
\text { deflection), } \\
\text { or max(tip } \\
\text { blocked force), } \\
\text { or max(actual } \\
\text { force) }\end{array}$ & $\begin{array}{l}\text { Ratio of } \\
\text { thicknesses } \\
\text { or Young's } \\
\text { moduli, or length }\end{array}$ & $\begin{array}{l}\text { Constraint } \\
\text { on total } \\
\text { thickness }\end{array}$ & $\begin{array}{l}\text { Analytical } \\
\text { solution } \\
\text { of optimality } \\
\text { condition }\end{array}$ & $\begin{array}{l}\text { PZT bimorph, } \\
\text { magnetostrictive } \\
\text { bimorph }\end{array}$ & MEMS \\
\hline $\begin{array}{l}\text { Lu } \\
\text { et al. (2001) }\end{array}$ & Min(weight) & $\begin{array}{l}\text { Plate thickness, } \\
\text { core member } \\
\text { thickness, total } \\
\text { length, total height }\end{array}$ & $\begin{array}{l}\text { Lower limit } \\
\text { on deflection, } \\
\text { upper limit on } \\
\text { power consumption, } \\
\text { upper limit on } \\
\text { stresses, buckling } \\
\text { constraints, lower } \\
\text { limit on fundamental } \\
\text { frequency }\end{array}$ & $\begin{array}{l}\text { Graphical and } \\
\text { SQP }\end{array}$ & SMA plate & $\begin{array}{l}\text { Active beam } \\
\text { with corrugated } \\
\text { core }\end{array}$ \\
\hline Begg and Liu (2000) & $\begin{array}{l}\text { Min(quadratic } \\
\text { index), or } \\
\text { max(robustness), } \\
\text { or max } \\
\text { (controllability) }\end{array}$ & $\begin{array}{l}\text { Cross sectional } \\
\text { areas of truss } \\
\text { elements, shape } \\
\text { function parameter, } \\
\text { actuator locations }\end{array}$ & $\begin{array}{l}\text { Upper limit on } \\
\text { weight, specified } \\
\text { fundamental } \\
\text { frequency }\end{array}$ & $\begin{array}{l}\text { SA with SLP } \\
\text { or SQP }\end{array}$ & $\begin{array}{l}\text { Generic force } \\
\text { generating } \\
\text { actuators }\end{array}$ & $\begin{array}{l}\text { 2-bar truss, } \\
\text { 25-bar truss }\end{array}$ \\
\hline $\begin{array}{l}\text { Franco Correia } \\
\text { et al. (2001) }\end{array}$ & $\begin{array}{l}\text { max(plate } \\
\text { deflection) or } \\
\text { max(fundamental } \\
\text { frequency) }\end{array}$ & $\begin{array}{l}\text { Actuator locations, } \\
\text { fiber angles in } \\
\text { each ply }\end{array}$ & Unconstrained & SA & $\begin{array}{l}8 \text { pairs of } \\
\text { square } \\
\text { piezoelectric } \\
\text { actuator } \\
\text { patches }\end{array}$ & $\begin{array}{l}\text { Simply supported } \\
\text { rectangular plate }\end{array}$ \\
\hline $\begin{array}{l}\text { Chattopadhyay } \\
\text { et al. (1999) }\end{array}$ & $\begin{array}{l}\text { Min(static } \\
\text { displacement), } \\
\text { and min(twist } \\
\text { of wing tip), } \\
\text { and min(acceleration } \\
\text { of tip), and max } \\
\text { (closed loop } \\
\text { damping ratio } \\
\text { of first mode) }\end{array}$ & $\begin{array}{l}\text { Composite stacking } \\
\text { sequence, } \\
\text { actuator/sensor } \\
\text { locations, controller } \\
\text { gain }\end{array}$ & $\begin{array}{l}\text { No overlap } \\
\text { of actuator } \\
\text { patches, limit } \\
\text { on actuator } \\
\text { dimensions, upper } \\
\text { limit on electric } \\
\text { power consumption, } \\
\text { upper limit on } \\
\text { ply stresses }\end{array}$ & $\begin{array}{l}\text { SA and } \\
\text { SQP hybrid }\end{array}$ & $\begin{array}{l}\text { Piezoelectric } \\
\text { actuator and } \\
\text { sensor patches }\end{array}$ & $\begin{array}{l}\text { Active wing } \\
\text { modeled as } \\
\text { flat cantilevered } \\
\text { composite plate }\end{array}$ \\
\hline
\end{tabular}

Although the authors call the resulting structure a smart structure, the type of actuators is not specified; they are assumed to be generic force generating actuators. The method is applied to a two-bar truss problem and compared to an exact solution, and also to a 25-bar truss problem.

Optimal design of active composite plates is considered by Franco Correia et al. (2001). They seek to maximize the transverse deflection of the midpoint of plate or to maximize its fundamental frequency. The location of eight pairs of square actuator patches and the fiber angles in each ply of the passive layers are the design variables. A refined finite element model is developed which uses higher order displacements so that the actuator size can be taken as the element size. The authors compare a simulated annealing solution algorithm to a gradient-based method and conclude that the SA algorithm takes 20 times longer than each trial of the gradient-based approach.

Chattopadhyay et al. (1999) address the structureactuator problem together with controller parameters for an active wing application. The active wing is modeled as a flat cantilevered composite plate, and the composite stacking sequence, the actuator/sensor locations defined in terms of centroid location, and the controller gain are optimized. Several objective functions are considered in multicriteria objective such as minimizing the static displacement, and minimizing the twist of the wing tip, and minimizing the acceleration of tip, and maximizing the closed loop damping ratio of the first mode. Constraints include prevention of overlap of actuator patches, limits on actuator dimensions, an upper limit on the electric power consumption during gust response analysis, and upper limit on ply stresses. A hybrid solution method is used where SA handles the discrete variables of stacking sequence and actuator/sensor placement, and SQP handles the continuous variable of feedback gain. Surface bonded rectangular piezoelectric sensors and actuators are assumed to be bonded in symmetric pairs to the top and bottom surfaces. The method is shown to be highly effective in reducing the acceleration at the tip due to gust and in handling all the objectives simultaneously. 


\section{CONCLUSIONS}

A truly optimized smart structure would be one where the actuators, sensors, structure, controller, and electronics have all been simultaneously designed to work in perfect harmony. This most general problem is quite difficult to handle, though, due to the complexity in modeling the interactions between all the subsystems in dynamic situations, and the computational effort required to analyze and optimize such a system. Portions of this general problem have been addressed by the authors mentioned in this paper using various approaches and solution techniques.

A promising area of future research is the development of topology optimization methods to simultaneously design the structure and actuator, and possibly the electronics and control system. The papers mentioned in Table 5 have assumed that the actuator elements are predetermined, i.e., their topology is not simultaneously optimized with the surrounding structure. A more general problem is to include the actuator elements in the optimization. Several authors have developed topology optimization methods for structures of multiple materials (Sigmund, 2001; Yin and Ananthasuresh, 2001), but piezoelectric actuation has not been directly addressed. Optimization of the topology of a piezoceramic transducer has been accomplished by Nelli Silva and Kikuchi (1999), but the ceramic is not considered simultaneously with the coupling structure. As the authors point out, piezoceramic actuators of complex topologies are very difficult to manufacture. As a result, future research efforts should be directed at incorporating practically available actuator materials such as piezoelectric stacks and/or bimorphs into topology optimization methods. As modeling and computational abilities improve, it will be possible to also incorporate electronics and control systems directly into the optimization.

\section{REFERENCES}

Adali, S.J., Bruch, J.C. and Sadek, I.S. et al. 2000. "Robust Shape Control of Beams with Load Uncertanties by Optimally Placed Piezo Actuators," Structural and Multidisciplinary Optimization, 19:274-281.

Aldraihem, O.J., Singh, T. and Wetherhold, R.C. 2000. "Optimal Size and Location of Piezoelectric Actuator/Sensors: Practical Considerations," Journal of Guidance, Control, and Dynamics, 23(3):500-515.

Barboni, R., Mannini, A. and Fantini, E. et al. 2000. "Optimal Placement of PZT Actuators for the Control of Beam Dynamics," Smart Materials and Structures, 9:110-120.

Begg, D.W. and Liu, X. 2000. "On Simultaneous Optimization of Smart Structures - Part II: Algorithms and Examples," Computer Methods in Applied Mechanics and Engineering, 184:25-37.

Bruant, I., Coffignal, G. and Lene, F. et al. 2001. "A Methodology for Determination of Piezoelectric Actuator and Sensor Location on Beam Structures," Journal of Sound and Vibration, 243(5):861882.

Canfield, S. and Frecker, M. 2000. "Topology Optimization of Compliant Mechanical Amplifiers for Piezoelectric Actuators," Structural and Multidisciplinary Optimization, 20(4):269-278.

Chandrasekaran, S., Lindner, D.K. and Smith, R.C. 2000. "Optimized Design of Switching Amplifiers for Piezoelectric Actuators," Journal of Intelligent Material Systems and Structures, 11(4):887-901.

Chattopadhyay, A., Seeley, C.E. and Jha, R. 1999. "Aeroelastic Tailoring Using Piezoelectric Actuation and Hybrid Optimization," Smart Materials and Structures, 8:83-91.

Du, H., Lau, G.K. and Lim, M.K. et al. 2000. "Topological Optimization of Mechanical Amplifiers for Piezoelectric Actuators Under Dynamic Motion," Smart Materials and Structures, 9:788-800.

Franco Correia, V.M., Mota Soares, C.M. and Mota Soares, C.A. 2001. "Refined Models for the Optimal Design of Adaptive Structures Using Simulated Annealing," Composite Structures, $54: 161-167$

Frecker, M. and Canfield, S. 2000. "Optimal Design and Experimental Validation of Compliant Mechanical Amplifiers for Piezoceramic Stack Actuators," Journal of Intelligent Material Systems and Structures, 11(5):360-369.

Gao, F., Shen, Y. and Li, L. 2000. "The Optimal Design of Piezoelectric Actuators for Plate Vibroacoustic Control Using Genetic Algorithms with Immune Diversity," Smart Materials and Structures, 9:485-491.

Gehring, G.A., Cooke, M.D. and Gregory, I.S. et al. 2000. "Cantilever Unified Theory and Optimization for Sensors and Actuators," Smart Materials and Structures, 9(6):918-931.

Han, J.-H. and Lee, I. 1999. "Optimal Placement of Piezoelectric Sensors and Actuators for Vibration Control of a Composite Plate Using Genetic Algorithms," Smart Materials and Structures, $8(2): 257-267$

Heverly II, D.E., Wang, K.W. and Smith, E.C. 2001. "An Optimal Actuator Placement Methodology for Active Control of Helicopter Airframe Vibration," Journal of the American Helicopter Society, 46(4):251-261.

Hiramoto, K., Dok, H. and Obinata, G. 2000. "Optimal Sensor/ Actuator Placement for Active Vibration Control Using Explicit Solution of Algerbraic Riccati Equation," Journal of Sound and Vibration, 229(5):1057-1075.

Kota, S., Hetrick, J. and Li, Z. et al. 1999. "Tailoring Unconventional Actuators Using Compliant Transmissions: Design Methods and Applications," IEEE/ASME Transactions on Mechatronics 4(4):396-408

Lau, G.K., Du, H. and Guo, N. et al. 2000. "Systematic Design of Displacement - Amplifying Mechanisms for Piezoelectric Stacked Actuators Using Topology Optimization," Journal of Intelligent Material Systems and Structures, 11:685-695.

Li, L.X., Shen, Y.P. and Gao, F. 2001. "The Optimal Design of Piezoelectric Actuators for Acoustic Control," Smart Materials and Structures, 10:421-426.

Lu, T.J., Hutchinson, J.W. and Evans, A.G. 2001. "Optimal Design of a Flexural Actuator," Journal of the Mechanics and Physics of Solids, 49:2071-2093.

Messac, A. 1996. "Physical Programming: Effective Optimization for Computational Design," AIAA Journal, 34(1):149-158.

Nelli Silva, E.C. and Kikuchi, N. 1999. "Design of Piezoelectric Transducers Using Topology Optimization," Smart Materials and Structures, 8:350-365.

Nelli Silva, E.C., Nishiwaki, S. and Fonseca, J.S.O. et al. 1999. "Optimization Methods Applied to Material and Flextensional Actuator Design Using the Homogenization Method," Computer Methods in Applied Mechanics and Engineering, 172:241271.

Nelli Silva, E.C., Nishiwaki, S. and Kikuchi, N. 2000. "Topology Optimization Design of Flextensional Actuators," IEEE Transactions and Ultrasonics Ferroelectrics, and Frequency Control, 47(3):657-671. 
Padula, S.L. and Kincaid, R.K. 1999. Optimization Strategies for Sensor and Actuator Placement, pp. 1-12, National Aeronautics and Space Administration Langley Research Center, Langley, Virginia 23681.

Sadri, A.M., Wright, J.R. and Wynne, R.J. 1999. "Modelling and Optimal Placement of Piezoelectric Actuators in Isotropic Plates Using Genetic Algorithms," Smart Materials and Structures, 8:490-498.

Sheng, L. and Kapania, R.K. (2001). "Genetic Algorithms for Optimization of Piezoelectric Actuator Locations," AIAA Journal, 39(9):1818-1822.

Sigmund, O. 2001. "Design of Multiphysics Actuators Using Topology Optimization - Part II: Two Material Structures," Computer Methods in Applied Mechanics and Engineering, 190:66056627.
Sigmund, O. and Torquato, S. 1999. "Design of Smart Composite Materials Using Topology Optimization," Smart Materials and Structures, 8(3):365-379.

Suleman, A. and Goncalves, M.A. 1999. "Multi-objective Optimization of an Adaptive Composite Beam Using the Physical Programming Approach," Journal of Intelligent Material Systems and Structures, 10:56-70.

Yin, L. and Ananthasuresh, G.K. 2001. "Topology Optimization of Compliant Mechanisms with Multiple Materials Using a Peak Function Interpolation Scheme," Structural and Multidisciplinary Optimization, 23(1):49-62.

Zhang, H., Lennox, B. and Goulding, P.R. et al. 2000. "A Floatencoded Genetic Algorithm Technique for Integrated Optimization of Piezoelectric Actuator and Sensor Placement and Feedback Gains," Smart Materials and Structures, 9:552-557. 